\title{
AKTIVITAS ANTIBAKTERI EKSTRAK POLAR DAN NON POLAR BIJI KELOR (Moringa oleifera) ASAL PULAU TIMOR NTT
}

\author{
Fredy Saudale ${ }^{1}$,Early Boelan ${ }^{1,2}$ \\ ${ }^{1} J u r u s a n$ Kimia, Fakultas Sains dan Teknik, Universitas Nusa Cendana \\ Kupang, NTT, Indonesia \\ ${ }^{2}$ Jurusan Pendidikan MIPA, Program Studi Pendidikan Kimia, Fakultas Keguruan dan IImu \\ Pendidikan, Universitas Katholik Widya Mandira \\ Kupang, NTT, Indonesia \\ e-mail: fredy_saudale@staf.undana.ac.id, earlygrizca@gmail.com
}

\begin{abstract}
Abstrak
Tumbuhan kelor (Moringa oleifera) telah digunakan dalam pengobatan tradisional. Namun demikian belum diketahui aktivitas antibakteri ekstrak biji kelor asal pulau Timor NTT pada bakteri E.coli dan S.aureus. Ekstrak non polar didapatkan dengan metode maserasi menggunakan n-heksana yang kemudian diidentifikasi komponen kimianya dengan GCMS. Ekstrak polar didapatkan dengan merebus biji kelor pada suhu $70 \circ \mathrm{C}$ menggunakan akuades. Dari hasil penelitian didapatkan bahwa kandungan terbesar pada ekstrak nonpolar adalah asam oktadek-9-enoat $(85,79 \%)$ yang adalah asam trans oleat dan asam-9oktadekanoat $(12,69 \%)$, suatu asam cis-oleat. Ekstrak polar pada konsentrasi optimum $100 \%$ memberikan daya hambat yang lebih besar yaitu $5,67 \mathrm{~mm}$ terhadap bakteri E. coli dan $7,33 \mathrm{~mm}$ terhadaps. aureus dibandingkan ekstrak non-polar yang memberikan daya hambat 4,67 mm terhadapE. coli dan $5,00 \mathrm{~mm} \mathrm{~S}$. aureus. Disimpulkan bahwa ekstrak polar dan nonpolar biji kelor menunjukkan aktivitas antibakteri E.coli dan S.aureus. Perbedaan daya hambat didugakarena perbedaan pada kandungan senyawa kimianya.
\end{abstract}

Kata kunci: Ekstrak biji, Moringa oleifera, antibakteri, daya hambat

\begin{abstract}
Moringa oleiferahas been widely used for traditional medicine. Nevertheless, antibacterial activity of Moringa seed extract from Timor Island in E.coli and S.aureushas been unknown. Non polar extract was obtained by maceration method using n-hexane which was then identified its chemical component with GC-MS. Polar extract was obtained by boiling Moringa seeds at $70^{\circ} \mathrm{C}$ using aquades. The results showed that the largest content of non-polar extract was octadec-9-enoat acid (85.79\%), atrans oleic acid and 9octadecanoic acid (12.69\%), a cis-oleic acid. Polar extract at concentration of $100 \%$ showed a larger inhibition of $5.67 \mathrm{~mm}$ for E. coli and $7.33 \mathrm{~mm}$ for S. aureus than non-polar extract; $4.67 \mathrm{~mm}$ inhibition for E. coli and $5.00 \mathrm{~mm} \mathrm{~S}$. aureus. It was concluded that polar and nonpolar extract of Moringa seeds exhibits antibacterial activity toward E.coli and S.aureus. The difference in inhibitory activity may be due to differences in the chemical content of the extracts.
\end{abstract}

Keywords : Moringa oleifera, seed extracts, antibacterial activity

\section{PENDAHULUAN}

Indonesia kaya akan sumber bahan alam yang secara turun temurun telah digunakan sebagai ramuan obat tradisional, salah satunya adalah tanaman kelor (Moringa oleifera). Pohon kelor merupakan tumbuhan perdu yang mampu beradaptasi dengan kondisi alam di pulau Timor di Nusa
Tenggara Timur dengan keadaan cuaca, dan kondisi tanah yang cukup kering. Walaupun secara lokal, masyarakat di pulau Timor telah memanfaatkan daun dari tumbuhan ini sebagai bahan makanan (sayuran), keberadaan tumbuhan ini masih belum mendapat perhatian dari masyarakat, secara khusus pemanfaatannya sebagai 
obat tradisional. Kelor merupakan jenis tumbuhan yang memiliki banyak manfaat dari akar, kulit batang, daun, buah bahkan bijinya. Berbagai manfaat tumbuhan kelor ini terus dieksplorasi sebagai sumber vitamin A, B $(1,2,3,6,7), C, D, E$ dan $K$, sumber mineral (tembaga, besi, kalium, magnesium, mangan dan zinc), sumber protein, antioksidan, antimikroba, bahan baku pembuatan sabun dan kosmetik, sampai pada manfaatnya sebagai penjernih air (Mahmood., Mugal dan Haq, 2010). Penelitian yang dilakukan oleh Bukar, Uba dan Oyeyi (2010) menunjukkan bahwa ekstrak biji kelor mampu menghambat pertumbuhan beberapa bakteri dan juga jamur. Vieira et al (2010) juga menguji aktivitas antibakteri dari ekstrak biji kelor yang kemudian dibandingkan dengan ekstrak sirsak dan didapati bahwa ekstrak biji kelor lebih efektif dalam menghambat pertumbuhan beberapa bakteri yang diuji yaitu Staphylococcus aureus, Vibrio cholerae dan Escherichia coli.Sementara itu, Goyal et al (2007) menunjukkan bahwa biji kelor mengandung senyawa 4-( $\alpha-L-r h a m n p y r a n o s y l o x y)$ benzyl isothiocyanate yang telah diidentifikasi memiliki aktivitas antimikroba.

Namun demikian sejauh ini belum pernah diketahui aktivitas antibakteri biji kelor asal Pulau Timor terhadap Escherichia coli dan Staphylococcus aureus. Bakteri Escherichia coli merupakan bakteri gram negatif yang menghasilkan enterotoksin penyebab diare (Volk dan Wheeler, 1990). Sedangkan, S.aureus dikenal sebagai bakteri gram positif penyebab infeksi pada tenggorokan, paru-paru dan sistem saraf (Tally, 1993). Penelitian ini bertujuan untuk mengetahui pengaruh ekstrak polar (akuades) dan non-polar (n-heksana) biji kelor dalam menghambat pertumbuhan bakteri E.coli dan S.aureus. Berapa konsentrasi optimum ekstrak akuades dan n-heksana biji kelor dalam menghambat bakteri E.coli dan S.aureus juga dipelajari. Selain itu kandungan senyawa-senyawa kimia pada ekstrak polar dan non polar juga dianalisis menggunakan data dari GC-MS maupun literatur.

\section{METODE}

\section{Waktu dan Tempat Penelitian}

Penelitian ini telah dilaksanakan pada bulan Februari - April 2012. Proses ekstraksi dikerjakan di Laboratorium Kimia Fakultas Sains dan Teknik Universitas Nusa Cendana Kupang, uji aktivitas antibakteri dikerjakan di Laboratorium Mikrobiologi Universitas Widya Mandira Kupang dan analisis senyawa kimia ekstrak n-heksan dilakukan di Laboratorium Organik Universitas Brawijaya Malang.

\section{Bahan}

Dalam penelitian ini bahan-bahan yang digunakan adalah: biji kelor, $\mathrm{NaCl}$ 0,9 $\%$, Nutrien Agar, n- heksan, akuades, kertas saring, sedangkan organisme yang menjadi obyek penelitian adalah bakteri Staphyllococcus aureus dan Escherichia coli yang telah diisolasi dan disediakan di Laboratorium Mikrobiologi Universitas Widya Mandira Kupang.

\section{Persiapan Ekstrak}

Sampel yang digunakan dalam penelitian ini adalah biji kelor (Moringa oleifera L) yang diambil dari Kelurahan Penfui (Kupang). Biji kelor dibersihkan dan dihancurkan dengan blender. Serbuk lalu diayak dan dikeringkan dalam oven $100^{\circ} \mathrm{C}$ selama 1 jam. Untuk ekstrak non-polar, sebanyak 120 gram serbuk dicampur dengan $600 \mathrm{ml}$ n-heksana; campuran digojok dan dibiarkan semalaman. Ekstrak yang didapat disaring dan filtratnya dievaporasi pada suhu $70^{\circ} \mathrm{C}$ sampai diperoleh ekstrak pekat. Kandungan kimia pada ekstrak dianalisis dengan GC-MS. Untuk ekstrak dengan menggunakan akuades dilakukan dengan mengambil 120 gram serbuk biji kelor kemudian direbus dalam $600 \mathrm{ml}$ akuades pada suhu $70{ }^{\circ} \mathrm{C}$ selama 30 menit dan disaring dengan menggunakan kertas saring dan dipisahkan lapisan supernatannya. Kemudian filtrat dimasukkan dalam freezer selama 96 jam (4hari).

\section{Uji Aktivitas Antibakteri}

Media yang digunakan adalah media Nutrien Agar (NA). Sebanyak 10 gram nutrient agar dilarutkan dalam $500 \mathrm{ml}$ 
akuades kemudian dipanaskan sampai mendidih sambal diaduk. Nutrien agar yang ada kemudian disterilisasi dalam autoclave pada suhu $121^{\circ} \mathrm{C}$ selama 30 menit.

Persiapan kuman uji dimulai dengan pembuatan lempeng agar. Masing-masing cawan Nutrien Agar diinokulasikan dengan biakan Staphyllococcus aureus dan Escherichia coli dengan teknik agar sebar yang kemudian diinkubasi pada suhu $37^{\circ} \mathrm{C}$ selama 24 jam. Setelah itu kuman hasil pembiakan diambil 1 mata ose kemudian dimasukkan ke dalam $9 \mathrm{ml} \mathrm{NaCl} 0.9 \%$ (sebagai pengenceran $10^{-1}$ ) dan dilakukan seterusnya sampai pengenceran $10^{-5}$. Dari pengenceran $10^{-5}$ dipindahkan $1 \mathrm{ml} \mathrm{ke}$ dalam cawan petri, kemudian dituangkan media agar setebal $1 \mathrm{~cm}$ secara perlahan agar merata dan dibiarkan.

Uji antibakteri dilakukan dengan metode zona bening. Kertas cakram yang berdiameter $1 \mathrm{~cm}$ dimasukkan ke dalam ekstrak n-heksana dan akuades dengan konsentrasi $25 \%, 50 \%, 75 \%$ dan $100 \%$ lalu dibiarkan selama 1 jam. Kemudian kertas cakram yang ada diambil dan diletakkan ke dalam cawan petri yang berisi nutrient agar. Setelah diinkubasi pada suhu $37^{\circ} \mathrm{C}$ selama 24 jam.

\section{Pengukuran Diameter Hambatan}

Ekstrak n-heksana dan akuades dari biji marungga yang diuji dalam berbagai variasi konsentrasi diamati dan kemudian diukur zona beningnya. Ekstrak dikatakan mempunyai aktivitas jika dapat menghambat bakteri. Daerah hambatan terlihat sebagai bagian yang bening di sektiar kertas cakram (diukur dalam millimeter).

\section{Teknik Analisis Data}

Rancangan penelitian yang digunakan adalah rancangan acak lengkap (RAL) dengan variasi konsentrasi $0 \%, 25 \%, 50 \%$, $75 \%$ dan $100 \%$. Data yang diperoleh merupakan hasil pengamatan secara laboratorium yang selanjutnya dianalisis dengan menggunakan statistic parametrik ANOVA satu arah dengan tingkat kepercayaan $95 \%$.

\section{HASIL DAN PEMBAHASAN}

Ekstrak tumbuhan yang diperoleh melalui ekstraksi dengan pelarut umumnya dilakukan dengan mereaksikan bahan yang akan diekstrak dengan jenis pelarut tertentu kemudian diikuti dengan pemisahan residu dengan filtrat. Dalam penelitian ini sampel biji kelor yang diambil ekstraknya dilarutkan dengan dua pelarut yaitu akuades dan nheksan secara terpisah. Sebelum dilakukan ekstraksi sampel biji kelor terlebih dahulu dikeringkan di dalam oven pada suhu 100 ${ }^{\circ} \mathrm{C}$ selama 1 jam, dengan tujuan untuk menghilangkan kadar air di dalamnya.

$$
\text { Menurut Markam (1975), }
$$

penghalusan jaringan tumbuhan harus dilakukan terlebih dahulu untuk mengekstraksi komponen aktif yang terkandung didalamnya. Oleh karena itu biji kelor yang telah dikeringkan kemudian dibuat menjadi serbuk atau bubuk kering dengan maksud untuk memperluas permukaan, kemudian dilakukan pengayakan untuk menyeragamkan ukuran partikel agar mempermudah kontak antara bahan dengan pelarutnya sehingga ekstraksi dapat berlangsung dengan baik.

Proses ekstraksi biji kelor dengan menggunakan pelarut n-heksan dilakukan adalah dengan cara maserasi. Metode ini dipilih karena sederhana. Untuk zat-zat yang tidak tahan panas, maserasi merupakan metode yang cocok. Proses maserasi pada penelitian ini dimulai dengan merendam 120 gram sampel serbuk biji kelor dengan $600 \mathrm{ml}$ pelarut n-heksan selama 24 jam. Setelah itu dilakukan pemisahan antara residu dan filtrat. Filtrat yang ada kemudian dievaporasi untuk memisahkan zat aktif dengan pelarutnya.Ekstrak n-heksana biji kelor yang didapat setelah evaporasi adalah 32 $\mathrm{ml}$ atau setara dengan 24,94 gram. Dengan demikian persen hasil (rendemen) eksrak nheksana biji kelor adalah $26,67 \%(\mathrm{v} / \mathrm{w})$ atau $20,78 \%$ (w/w). Sementara itu esktrak akuades biji kelor yang diperoleh adalah 62 $\mathrm{ml}$ atau setara dengan 54 gram. Dengan demikian persen hasil (rendemen) ekstrak 


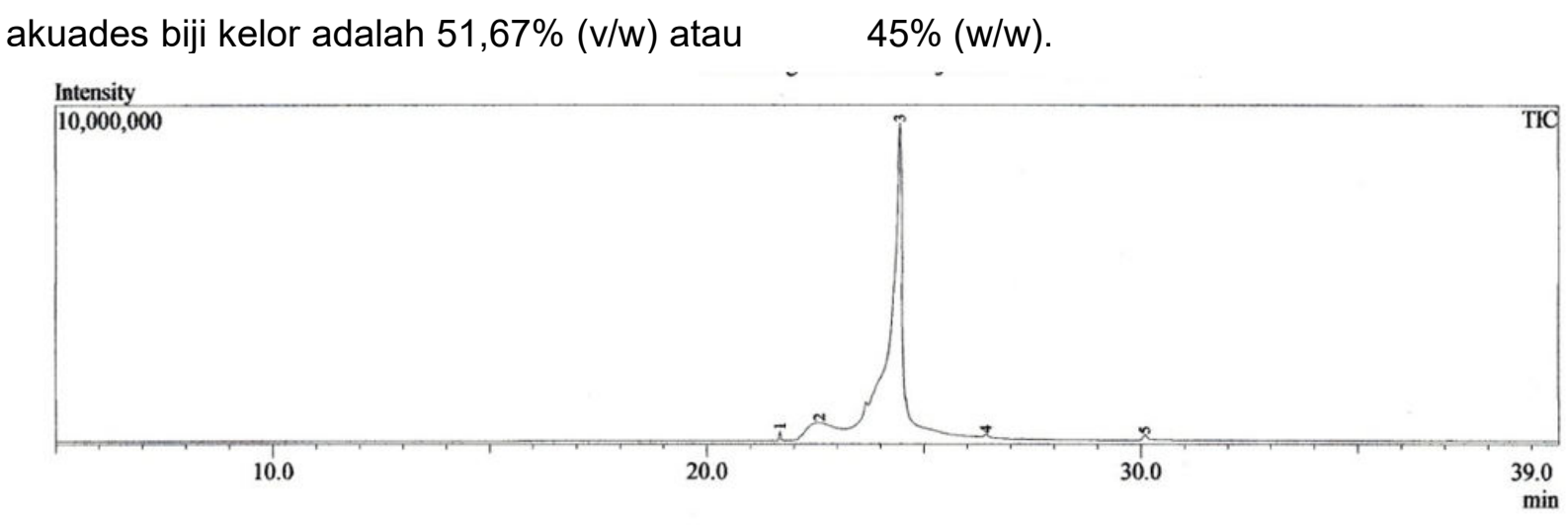

Gambar 1.K̈romatogram ekstrak n-heksana biji kelor

Berdasarkan hasil analisis dengan GC-MS dapat dilihat bahwa ekstrak nheksana biji kelor mengandung 5 komponen senyawa kimia yang ditunjukkan dengan adanya 5 puncak pada kromatogram (Gambar 1). Terlihat bahwa senyawa pada puncak ke-2 $\left(R_{t} 22,590\right.$ menit) dan 3 ( $R_{t}$ 24,472 menit) dengan persen area masing-masing adalah $12,69 \%$ dan $85,79 \%$ merupakan komponen yang paling dominan.Spektra massa pada puncak 2 dari kromatografi gas mempunyai ion molekuler dengan nilai $\mathrm{m} / \mathrm{e}=264$ pada waktu retensi 22,592 menit. Spektra dari senyawa ini mempunyai puncak dasar
55,05 dengan persen area 12,69\% (Gambar 2A). Berdasarkan berat molekul dan waktu retensi spektramassa senyawa tersebut memiiki rumusmolekul $\mathrm{C}_{18} \mathrm{H}_{34} \mathrm{O}_{2}$ dengan berat molekul sebesar 282 gram $/ \mathrm{mol}$ dan diduga bahwa senyawa tersebut adalah asam-9-oktadekanoat (Gambar 2B). Dugaan ini didukung oleh indeks bias kemiripan dimana spektra massa senyawa puncak 2 pada kromatogram memiliki indeks kemiripan sebesar 93\% dengan asam-9-oktadekanoat yang diduga merupakan asam oleat dalam bentuk cis.

A $\ll$ Target $\gg>$

Linetf:2 R.Time:22.592(Scan\#:2112) MassPeaks:87

RawMode:Averaged 22.583-22.600(2111-2113) BasePeak:55.05(26376) BG Mode:Calc. from Peak Group 1 - Evemt 1

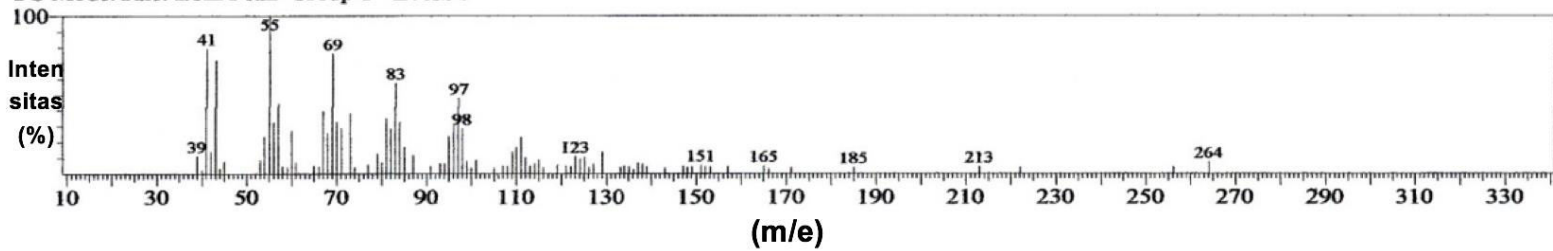

B Hitt:1 Entry:193349 Library:WILEY7.LIB

Hitt:1 Entry:193349 Library:WILEY7.LIB
SI:93 Formula:C18 H34 O2 CAS:112-80-1 MolWeight:282 RetIndex:0

SI:93 Formula:C18 H34 O2 CAS:112-80-1 MolWeight:282 Retlndex:0
CompName:9-Octadecenoic acid (Z)- (CAS) Oleic acid \$\$ Red oil \$\$ Oelsauere \$\$ Oleine $7503 \$$ Pamolyn 100 \$ Emersol 211 \$ Vopcolene $27 \$ \$$ cis100

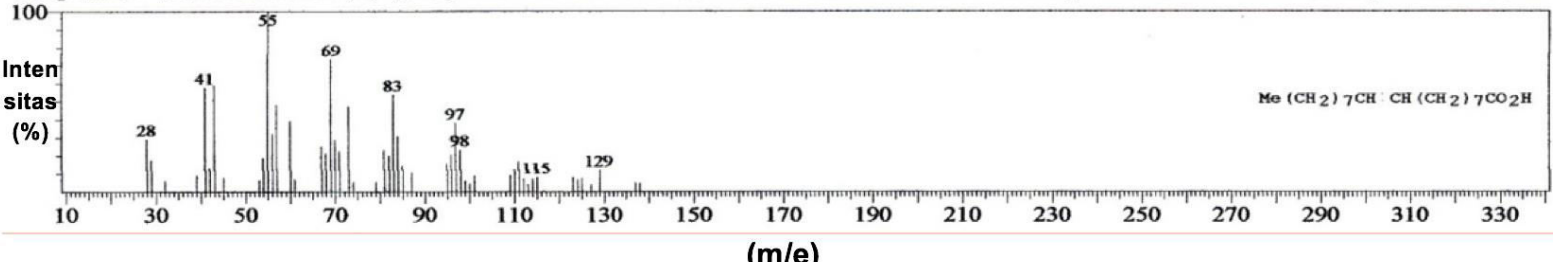

Gambar 2. Spektra Massa (A) dan Senyawa Referensi (B) pada Puncak ke-2 dari Kromatogram Gas ekstrak non polar

Spektra massa pada puncak 3 dari kromatografi gas mempunyai ion molekuler dengan $\mathrm{m} / \mathrm{e}=282$ pada waktu retensi
24,475 menit. Spektra massa dari senyawa ini mempunyai puncak dasar 55,05 dengan persen area $85,70 \%$ (Gambar 3A). 
A $\ll$ Target $>>$

Line\#:3 R.Time:24.475(Scan\#:2338) MassPeaks:188

RawMode:Averaged 24.467-24.483(2337-2339) BasePeak:55.05(776017)

BG Mode:Calc. from Peak Group 1 - Event 1

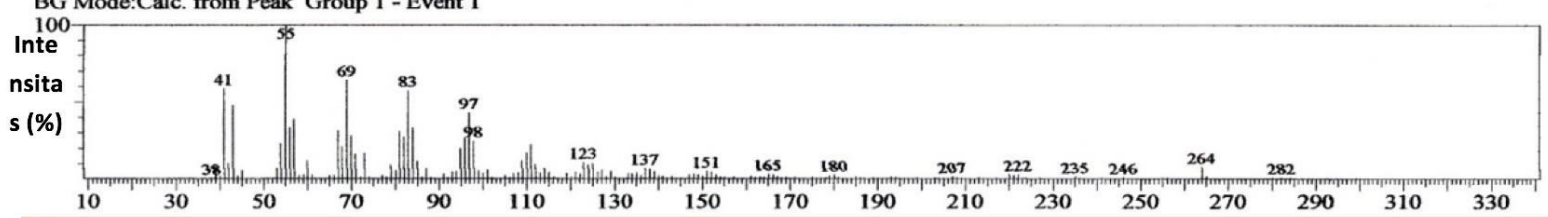

$(\mathbf{m} / \mathbf{e})$

B

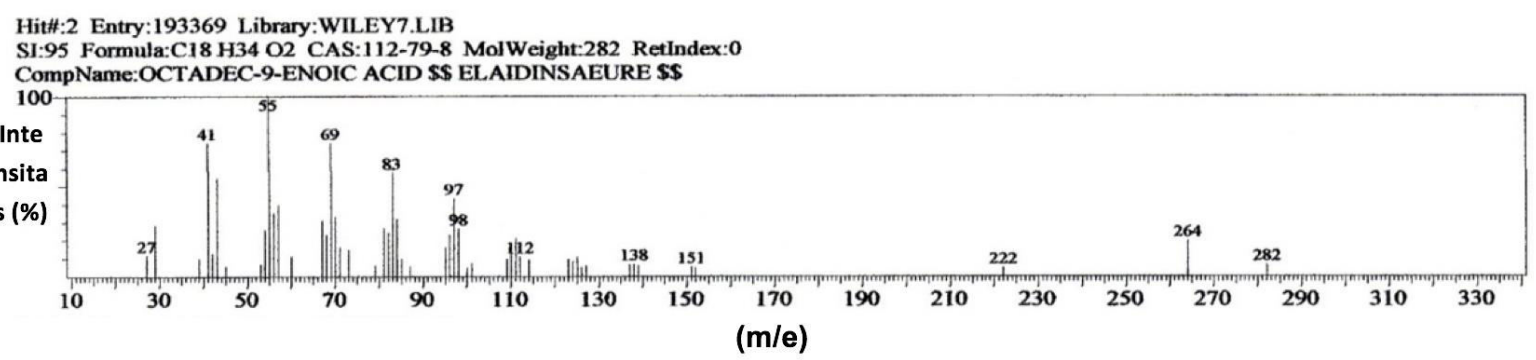

Gambar 3. Spektra Massa (A) dan Senyawa Referensi (B) pada Puncak ke-3 dari Kromatogram Gas ekstrak non polar

Berdasarkan berat molekul dan waktu retensi spektra massa senyawa tersebut memiliki rumus molekul $\mathrm{C}_{18} \mathrm{H}_{34} \mathrm{O}_{2}$ dengan berat molekul 282 gram dan diduga bahwa senyawa tersebut adalah asam oktadek-9enoat (Gambar 3B). Dugaan ini didukung oleh indeks bias kemiripan dimana spektra massa senyawa puncak 3 pada kromatogram memiliki indeks kemiripan sebesar 95\% dengan asam oktadek-9enoat yang kemungkinan adalah asam oleat dalam bentuk trans. Waktu retensi (Rt), persen area dan nama komponen dapat dilihat pada tabel 1 .

Tabel 1. Waktu Retensi (Rt), Persen Area (\%) dan

Perkiraan Nama Senyawa Ekstrak Non Polar hasil analisis Kromatografi Gas

\begin{tabular}{cccc}
\hline Puncak & $\begin{array}{c}\text { Waktu } \\
\text { Retensi, } \\
\text { Rt (menit) }\end{array}$ & $\begin{array}{c}\text { Persen } \\
\text { Area } \\
(\%)\end{array}$ & Senyawa \\
\hline 1 & 21,675 & 0,39 & Metil Palmitat \\
2 & 22,590 & 12,69 & Asam 9-oktadekanoat \\
3 & 24,472 & 85,79 & Asam Oktadek-9-enoat \\
4 & 26,428 & 0,38 & Gliserol-1,3-di Oktadekanoat \\
5 & 30,093 & 0,74 & Di-(9-oktadekenoil)-gliserol \\
\hline
\end{tabular}

Ekstrak akuades dan n-heksana biji kelor yang diperoleh dibuat larutan stok dengan konsentrasi $25 \%, 50 \%, 75 \%$ dan $100 \%$ yang kemudian dilakukan uji terhadap bakteri gram negatif (Escherichia coli) dan bakteri gram positif (Staphylococcus aureus). Sebagai kontrol positif digunakan San Prima tablet untuk E.coli; sedangkan Penisilin untuk S.aureus masing-masing dengan konsentrasi $10 \%$. Kontrol negatif adalah konsentrasi $0 \%$ dimana tidak dilakukan penambahan ekstrak terhadap bakteri uji. Ekstrak polar pada konsentrasi optimum 100\% memberikan rerata daya hambat yang lebih besar yaitu $5,67 \mathrm{~mm}$ untuk bakteri $E$. coli dan 7,33 mm untuk $S$. aureus (Gambar 4 dan 6) dibandingkan ekstrak non-polar yang memberikan rerata daya hambat $4,67 \mathrm{~mm}$ untuk $E$. coli dan $5,00 \mathrm{~mm} S$. Aureus pada konsentrasi 100\% (Gambar 5 dan 7). Luas zona hambat antibiotik sebagai kontrol positif adalah $4,33 \mathrm{~mm}$ terhadap E.coli dan $6,33 \mathrm{~mm}$ terhadap S.aureus.Secara umum terlihat bahwa semakin tinggi konsentrasi, semakin besar pula daya hambat yang 
diberikan pada pertumbuhan bakteri.

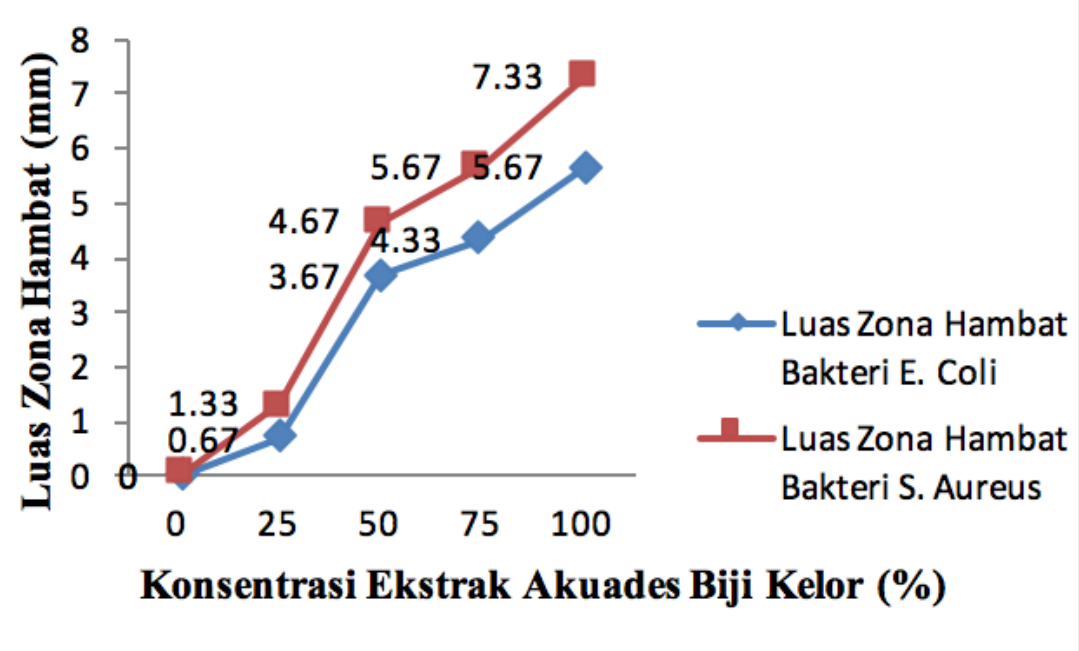

Gambar 4. Kurva hubungan antara konsentrasi ekstrak akuades terhadap luas zona hambatan pada bakteri E. coli dan S. aureus

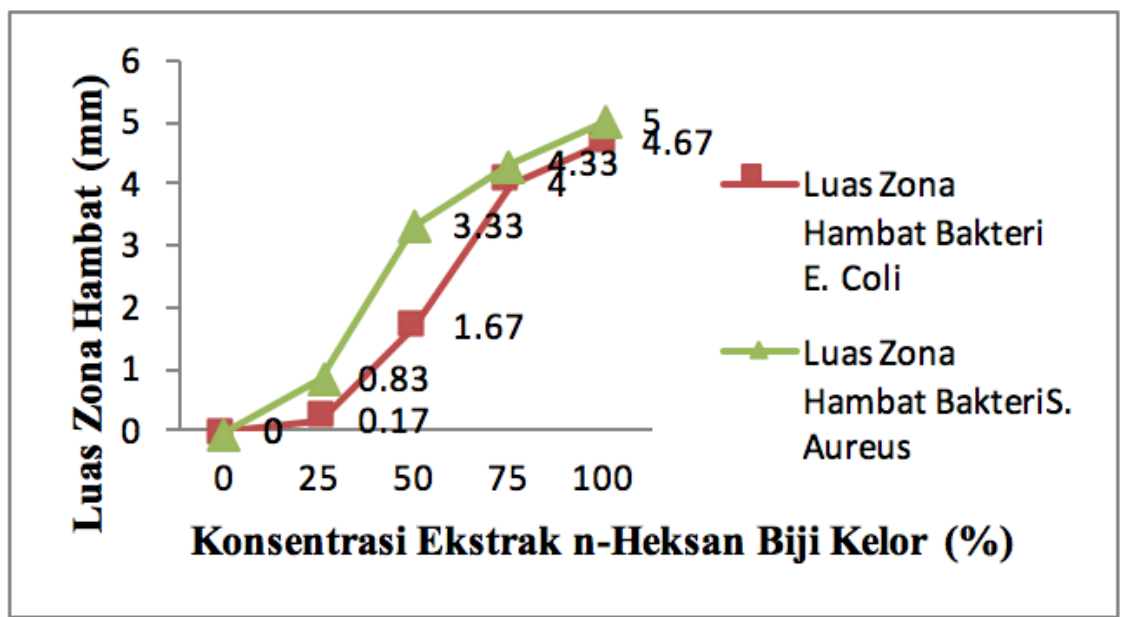

Gambar 5. Kurva hubungan antara konsentrasi ekstrak non polar terhadap luas zona hambatan pada bakteri $E$. coli dan $S$. aureus

Berdasarkan penggolongan menurut Suryawiria (1978) dari peneitian ini dapat dikategorikan bahwa ekstrak n-heksana biji kelor memberikan daya hambat yang sedang pada konsentrasi $100 \%$. Sementara itu pada konsentrasi $50 \%$ dan $75 \%$ memberikan daya hambat yang lemah, dan pada $25 \%$ hampir tidak memberikan daya hambat. Sedangkan untuk esktrak akuades biji kelor mempunyai daya hambat sedang pada konsentrasi $75 \%$ dan $100 \%$, dan lemah pada $25 \%$ dan $50 \%$. Konsentrasi $0 \%$ sama sekali tidak memberikan daya hambat. Efektifitas yang lemah dan sedang di duga karena ekstrak biji kelor yang digunakan masih merupakan ekstrak kasar yang kemungkinan masih terdapat kontaminan-kontaminan yang lain. 

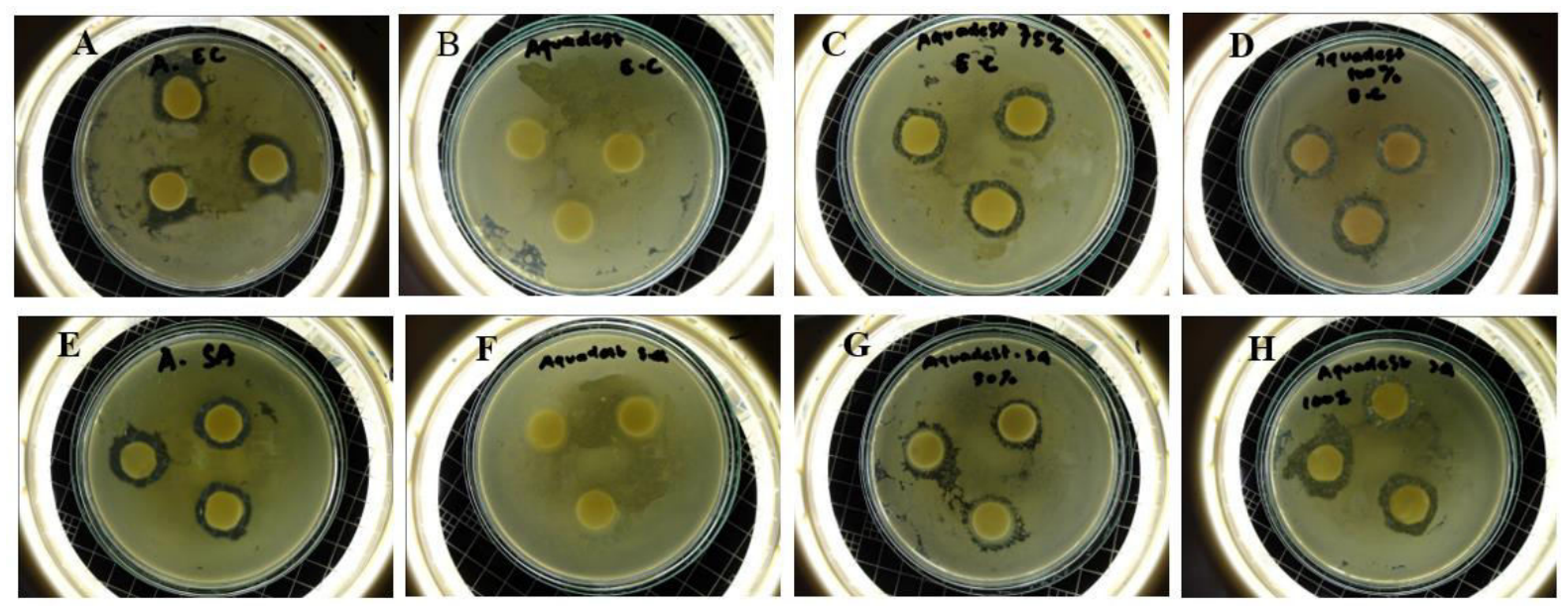

Gambar 6. Zona hambat dari uji antibakteri dari ektrak polar biji kelor konsentrasi (B) $0 \%$, (C) $50 \%$ dan(D) $100 \%$ terhadap pertumbuhan bakteri E.coli dan S.aureus. Panel A dan E adalah antibiotika $10 \%$ sebagai kontrol positif
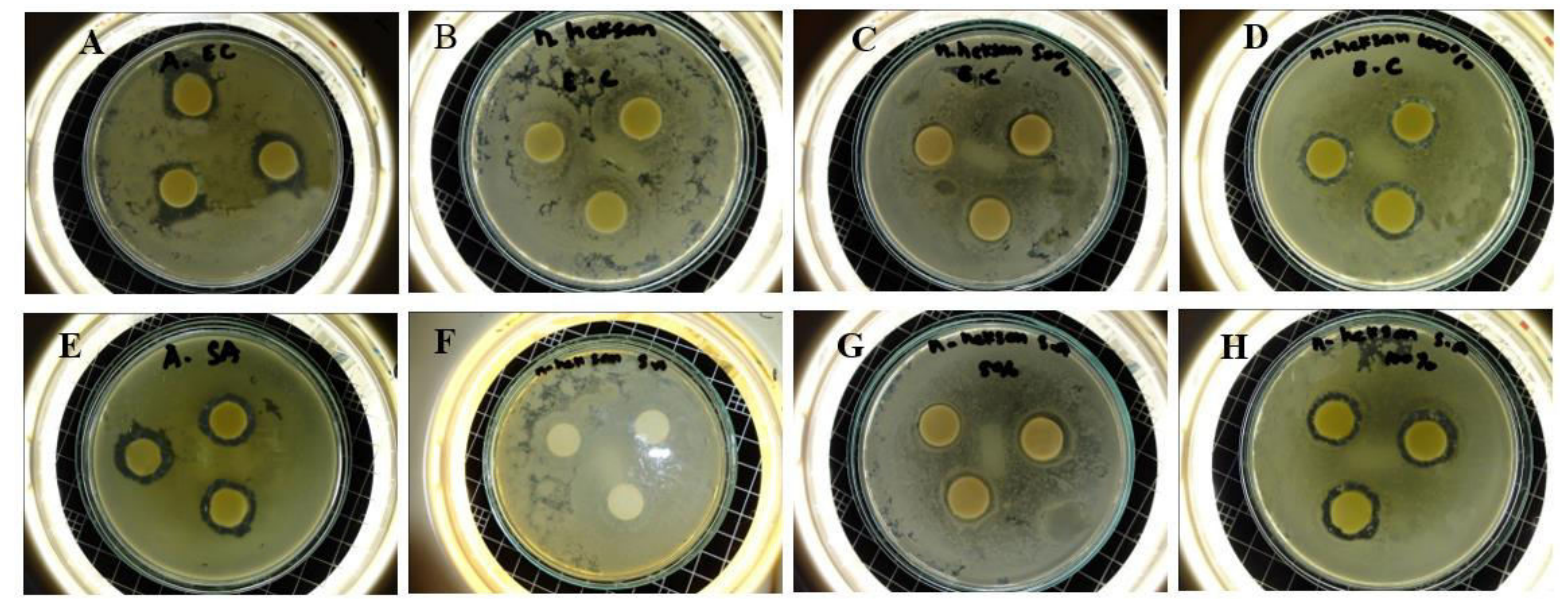

Gambar 7. Zona hambat dari uji antibakteri dari ektrak n-heksana biji kelor konsentrasi (B) $0 \%$, (C) $50 \%$ dan(D) $100 \%$ terhadap pertumbuhan bakteri E.coli dan S.aureus. Panel A dan E adalah antibiotika $10 \%$ sebagai kontrol positif

Dari hasil yang diperoleh dari penelitian ini didapatkan bahwa ekstrak nheksan dan akuades dari biji kelor mempunyai kemampuan mengahmbat bakteri E. coli dan S. aureus. Ekstrak akuadesmemiliki daya hambat yang lebih baik dibandingkan dengan ekstrak n-heksan. Apa yang menjelaskan perbedaan ini masih memerlukan penelitian lebih lanjut. Namun demikian dari kajian literatur diketahui bahwa di dalam ekstrak akuades terdapat senyawa toksik yaitu 4-( $\alpha$-L-rhamnopyranosyloxy) benzyl isothiocyanate (Eilert et al., 1981).Senyawa 4-( $\alpha$-L-rhamnopyrabenzyl isothiocyanate berhasil diisolasi dari biji kelor oleh Ragasa dkk (2012) dan setelah diuji ternyata senyawa ini mempunyai sifat toksisitas yang kuat terhadap beberapa kultur sel kanker manusia.Oluduro $d k k$ (2012) juga telah berhasil mengisolasi senyawa-senyawa dari ekstrak akuades dan metanol biji kelor yang memiliki daya hambat yang tinggi terhadap pertumbuhan beberapa bakteri gram positif dan negatif.Adanya senyawa-senyawa bioaktif yang bersifat toksik dalam ekstrak polar biji kelor inilah kemungkinan menyebabkan daya hambat ekstrak polar (akuades) terhadap bakteri $E$. coli dan S. aureus lebih besar dibandingkan ekstrak non-polar ( $\mathrm{n}$ heksan). 
Pertumbuhan bakteri S.aureus terlihat lebih sensitif terhadap ekstrak polar dan non polar biji kelor pada konsentrasi yang sama. Menurut Kalemba dan Kunicka (2003) aktivitas antibakteri tergantung pada tipe mikroorganisme, gram positif atau gram negatif, terutama struktur dinding sel maupun membrane luar. Perbedaan struktur dinding sel menentukan penetrasi dan aktivitas senyawa antibakteri. Bakteri gram positif cenderung lebih sensitif terhadap antibakteri, karena struktur dinding sel bakteri gram positif lebih sederhana dibandingkan dengan bakteri gram negatif sehingga memudahkan senyawa antibakteri untuk masuk ke dalam sel. Umumnya bakteri gram negatif mengandung membran luar yang dapat menghalangi masuknya molekul-molekulel besar. Resistansi yang disebabkan karena tingkat ketebalan dinding sel ini juga yang membuat ekstrak tanaman maupun antibiotik menunjukkan pengaruh yang berbeda-beda pula.

Dari berbagai konsentrasi ekstrak didapati zona hambat yang bervariasi dan tidak berupa lingkaran yang sempurna. Hal ini disebahkan karena adanya ketebalan medium agar yang tidak seragam, variasi difusi ekstrak tumbuhan, sensitivitas bakteri uji terhadap senyawa antibakteri dalam ekstrak, serta konsentrasi senyawa antibakteri dalam ekstrak. Ketebalan medium agar yang tidak seragam merupakan hal teknis yang sulit dihindari karena pada saat penuangan Nutrient Agar ke dalam cawan petri tidak sama persis banyaknya. Variasi difusi ekstrak tumbuhan yang terjadi diakibatkan karena kertas cakram mempunyai komposisi yang heterogen sehingga zona hambat yang terbentuk tidak merata. Sensitivitas bakteri uji terhadap senyawa antibakteri dalam ekstrak tumbuhan juga merupakan salah satu faktor yang mempengaruhi diameter zona hambat. Jika konsentrasi bakteri uji pada media tinggi, maka diperlukan senyawa antibakteri dengan konsentrasi tinggi pula. Jika konsentrasi diantara keduanya tidak sebanding maka akan terlihat pada diameter zona hambatnya (lebar, sempit atau bahkan tidak ada sama sekali).
Biji kelor telah dilaporkan mempunyai sifat antimikroba terhadap beberapa bakteri gram positif dan gram negatif (Anwar et al., 2007; Oluduro et al., 2012). Biji kelor kaya akan komponen-komponen antimikroba yang mengandung gula sederhana, rhamnosa dengan sekelompok senyawa turunan glucosinolates dan isothiocyanates seperti 4-( $\alpha$-L-rhamnopyranosyloxy) benzylglucosinolate dan benzylisothiocyanates (Fahey et al., 2001; Bennet et al., 2003). Seperti telah dijelaskan diatas efek antimikroba dari biji kelor nampaknya ditentukan oleh adanya senyawa toksik aktif 4-( $\alpha$-Lrhamnopyranosyloxy) benzyl isothiocyanate (Eilert et al., 1981).

Oluduro et al (2012) berhasil mengisolasi senyawa aktif dari ekstrak akuades dan metanol biji kelor yang merupakan turunan dari phenylmethanamine, benzyl isothiocyanate dan carbamate yang memiliki daya hambat yang tinggi terhadap beberapa bakteri gram positif dan gram negatif. Senyawa-senyawa yang berhasil diisolasi adalah 4hydroxyphenyl acetic acid, 4-(4'-O-acetyl-aL-rhamnopyranosyloxy) benzyl isothiocyanate, 4-( $\beta$-D-glucopyranosyl-1 $\rightarrow$ 4- $\alpha$-L-rhamnopyranosyloxyl) benzyl isothiocyanate, $\quad 4-\mathrm{O}-\alpha-\mathrm{L}-$ rhamnopyranosyloxy-N-glucopyranosyl$1 \rightarrow 2$-fructopyranosyloxy phenylmetanamine, dan O-methyl-4-(4'-Oacetyl- $\alpha$-L-rhamnosyloxy)-benzyl thiocarbamate.

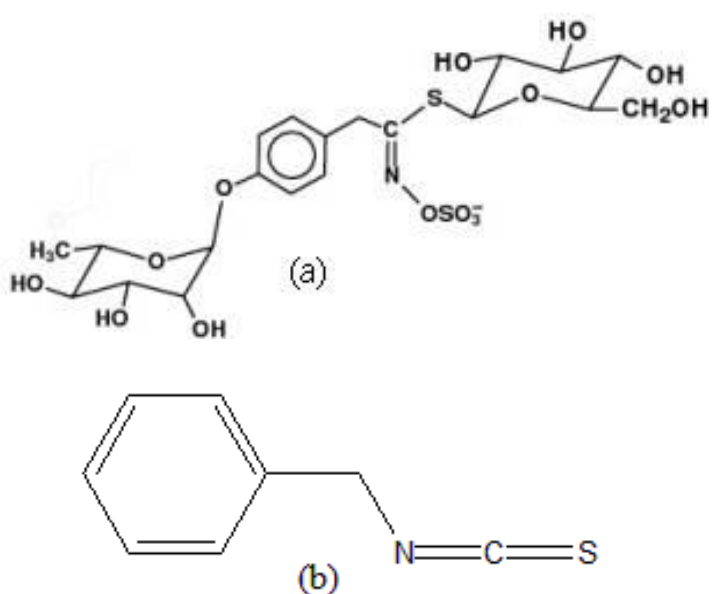

(b) 


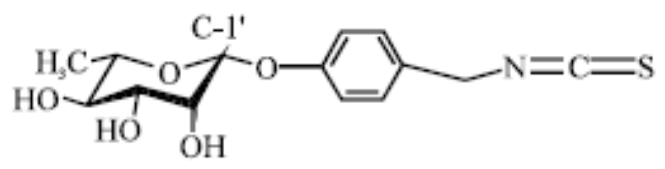

(d)

(c)<smiles>CC(=O)OC1C2CC1C(O)C(O)C(Oc1ccc(CN=C=S)cc1)O2</smiles>

(e)

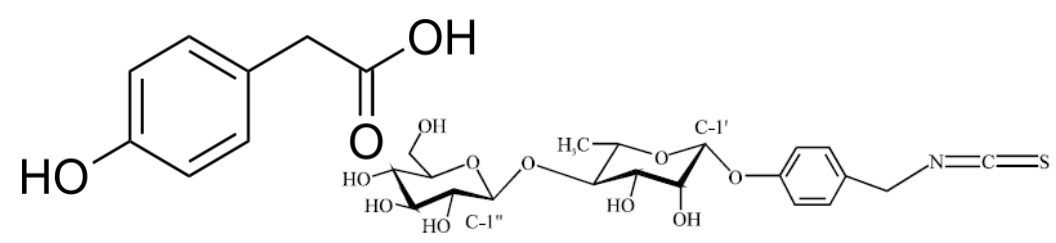

(f)

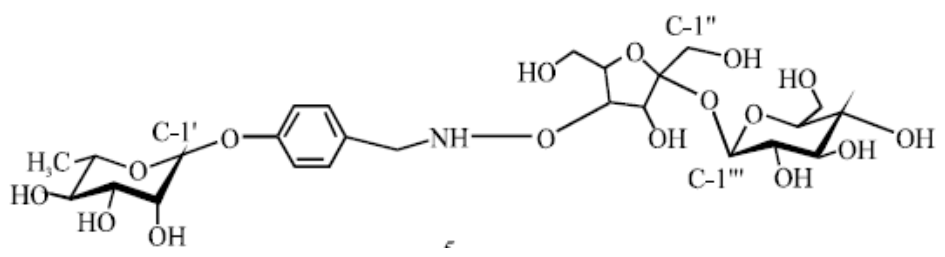

(g)

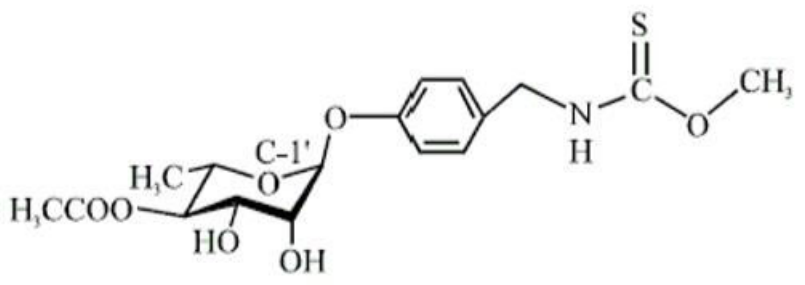

(h)

Gambar 8. Senyawa yang terkandung dalam ekstrak polar biji kelor (a) 4-( $\alpha-L$ rhamnopyranosyloxy)-benzylglucosinolate; (b) benzylisothiocyanates; (c)4-( $\alpha-\mathrm{L}$ rhamnpyranosyloxy) benzyl isothiocyanate;(d) 4-hydroxyphenyl acetic acid; (e) 4-(4'-O-acetyl-aL-rhamnosyloxy) benzil isothiocyanate; (f) 4-( $\beta$-D-glucopyranosyl-1 \& $4-\alpha-L-$ rhamnopyranosyloxyl) benzil isotiosianat; (g) 4-O- $\alpha-\mathrm{L}-$ rhamnopyranosyloxy-N-glucopyranosyl1 e 2-fructopyranosyloxy phenylmetanamine; (h) O-methyl-4-(4'-O-acetyl-a-L-rhamnosyloxy)benzyl thiocarbamate.

Berdasarkan kajian literatur yang ada, maka kemungkinan senyawa-senyawa bioaktif yang bersifat toksik tersebut diataslah yang menjadi faktor yang menjelaskan mengapa daya hambat ekstrak polar akuades biji kelor terhadap E.coli dan S.aureus lebih besar dibandingkan ekstrak heksana yang lebih bersifat non-polar. 


\section{SIMPULAN}

Ekstrak polar (akuades) biji kelor memberikan daya hambat yang lebih besar terhadap pertumbuhan bakteri Staphylococcus aureus dan Escherichia coli dibandingkan dengan ekstrak non-polar(nheksana). Semakin besar konsentrasi esktrak akuades dan n-heksana biji kelor maka semakin besar pula daya hambatnya terhadap pertumbuhan bakteri Escherichila coli dan Staphylococcus aureus. Ekstrak non polar biji kelor kaya dengan asam lemak cis dan trans oleat;

Namun demikian perlu diteliti lebih lanjut peranan asam-asam lemak tersebut dalam menghambat pertumbuhan bakteri gram positif dan negatif. Selain itu perlu juga dianalisis kandungan kimia dari ekstrak polar dari biji kelor. Pemurnian senyawa-senyawa kimia dari ekstrak polar dan non polar biji kelor perlu diteliti lebih lanjut dan juga perlu dipelajari mekanisme aktivitas antibakterinya dalam menghambat pertumbuhan mikroorganisme patogenik.

\section{DAFTARPUSTAKA}

Bukar, A., Uba, A., and Oyeyi, T.I., 2010, Antimikrobial Profile Moringa Oleifera Lam. Extracts Againts SomeFoodBorne Microorganisms, Bayero Journal of Pure and Applied Sciences, 3(1):4348.

Vieira, G.H.F., Mourao, J.A., Angelo, A.M., Costa, R.A and Vieira, R.H., 2010, Antibacterial Effect (in vintro) Of Moringa oleifera and Annona muricata Against Garam Positive and Gram Negative

Bacteria,Rev.Inst.Med.Trop.Sao Paulo, 53 (3):129-132

Goyal, B.R., Agrawal, B.B., Goyal, R.K., dan Mehta, A.A., 2007, Phytopharmacology of Moringa oleifera Lamk. ó An overview, Natural Product Radiance, Vol 6(4), pp 347-353.

Volk dan Wheeler, 1990, Mikrobiologi Dasar Edisi Kelima Jilid Dua, Erlangga:Jakarta.

Tally, F. P. 1993. Staphylococci: abscesses and other diseases. Dalam : Schaechter, M. (ed.) Mechanisms of
MicrobialDiseases. 2nd Ed. Williams and Wilkins, USA. h. 187-197.

Suryawira, U., 1978, Mikroba Lingkungan. Edisi ke- 2, ITB: Bandung.

Eilert, U., Wolters, B., Nadrtedt, A., 1981, The Antibiotic Principle of seeds of Moringa oleifera and Moringa stenopetala, Planta Med, 42:55-61

Ragasa, C.Y., Levida, R.M., Don, M.J., dan Shen, C.C., 2012, Cytotoxic Isothiocyanates from Moringa oleifera Lam Seeds. Phillippine Science Letters $5(1): 46-52$

Oluduro, O.A., Idowu, T.O., Aderiye,B.I., Famurewa, O dan Omoboye,O.O., 2012, Evaluation of Antibacterial Potential of Crude Extract of Moringa oleifera seed on Orthopaedics Wound Isolates and Characterization ofPhenylmethanamine and Benzyl Isothiocyanate Derivatives. Research Journal of Medicinal Plant.1-12

Kalemba, D dan Kunicka, A., 2003, Antibacterial and antifungal properties of essential oils, Current Medicinal Chemistry, 10 (10): 813-829.

Mahmood, K.T., Mugal, T and Haq, I.U., 2010, Moringa a natural gift-A Reiview, J. Pham. Sci. \& Re,Vol.2 (11), 775-781

Markam KR 1975. Isolation Techniques for Flavanoid. New York: The

Flavanoids Academic Press.

Anwar, F., Sajid, Latid., Muhammad, Ashraf., dan Anwarul, Hassan.Gilani., 2007, Moringa oleifera: A Food Plant with Multiple Medicinal Uses. Phytotherapy Research, 21:17-25.

Bennet, R.N., Mellon, F.A., Foldi, N., et al. 2003, Profiling glucosinolates and phenolics in vegetative and reproductive tissues of the multipurpose trees Moringa oleifera $\mathrm{L}$ (Horseradish tree) and Moringa stenopetala L. J Agric Food Chem, 51:3546-3553

Fahey, J.W., Zalcmann, A.T., Talalay, P., 2001, The chemical diversity and distribution of glucosinolates and isothiocyanates among plants, Phytochemistry, 56:5-51 